\title{
Investigation of Patients with Hippocampal Sclerosis Associated with Unusual Epileptic Activities
} Hipokampal Skleroz Olgularında Olağan Dışı Epileptik Aktivitelerin Araştırılması

Ebru Nur Vanlı Yavuz, Hakan Yener, Zeynep Aydın Özemir, Nerses Bebek, Candan Gürses, Ayşen Gökyiğit, Betül Baykan İstanbul University İstanbul Faculty of Medicine, Department of Neurology, Division of Clinical Neurophysiology, i̇stanbul, Turkey

\section{Summary}

Objective: Hippocampal sclerosis (HS) is usually associated with typical anterior temporal spikes/sharp waves in the electroencephalography (EEG). We aimed to investigate the clinical, electrophysiologic differences, and prognosis between HS patients with unusual epileptic foci in comparison with patients with typical foci.

Materials and Methods: Patients diagnosed who were diagnosed as having mesial temporal lobe epilepsy with HS in our center were included. All magnetic resonance imaging (MRI) results were investigated for the presence of two major criteria of HS diagnosis, namely T1 atrophy and T2 hyperintensity. All EEG and video-EEG investigations (a total of 496) were re-evaluated for unusual epileptic activities except T1/2, F7/8, T3/4 foci. Clinical and other laboratory data were retrospectively reevaluated by two investigators and the groups with usual and unusual epileptic activities for this syndrome were statistically compared.

Results: A total of 124 patients including 20 (16.1\%) with unusual epileptic activities (group 1) and 104 patients with typical foci (group 2) were evaluated. We observed 11 posterior temporal (T5/T6), four frontal (F3/F4), four frontopolar (Fp1/2), two occipital (O1/O2), three central (CP/FC) unusual foci, and two generalized epileptiform discharges in these 20 patients. Impaired background activity, nonspecific interictal diffuse slowing, and atypical seizure offset patterns were more frequently observed in group 1. Forty-nine patients underwent surgery after appropriate preoperative diagnostics; there was no significant difference in the postoperative outcome between the groups despite a tendency to better prognosis in group 2.

Conclusion: Our study showed that unusual epileptic foci could be seen in $16.1 \%$ of patients with HS. Although some patients with HS have these atypical interictal EEG findings, they might obtain good post-operative outcomes when preoperative diagnostics are appropriately planned.

Keywords: Mesial temporal lobe epilepsy, hippocampal sclerosis, electroencephalography, prognosis

\section{$\ddot{\mathbf{O z}}$}

Amaç: Hipokampal skleroz (HS) genelde elektroensefalografide (EEG) ön temporal elektrotlarda görülen tipik dikenler/keskin dalgalar ile ilişkilidir. Çalışmada bu odaklardan farklı lokalizasyonlarda epileptik odakların ve aktivitelerin görüldüğü olguların, tipik odakları olanlara kıyasla klinik, elektrofizyolojik özelliklerinin ve prognoz farklarının araştırılması amaçlanmıştır.

Gereç ve Yöntem: Merkezimizde mezyal temporal lob epilepsisi ile giden HS tanısıyla takipli olgular çalışmaya dahil edildi. Tüm manyetik rezonans görüntülemeler (MRG) iki ana HS tanı kriterinin (hipokampal yapılarda atrofi ve T2 ya da FLAIR sekanslarında sinyal artışı) varlığı açısından incelendi. Tüm EEG ve video EEG incelemeleri (toplam 496 adet) T1/2, F7/8, T3/4 odakları dışında farklı bir alanda epileptik aktivitesi olan ve olmayan hastalar açısından incelendi. Klinik ve diğer laboratuvar incelemeleri iki araştırmacı tarafından retrospektif olarak değerlendirildi. Olağan dışı odağı olan hastalarla olağan dışı odağı olmayan hastalar istatistiksel yöntemlerle kiyaslandı.

Bulgular: Yirmisinde olağan dışı (\%16,1) epileptik aktivite olan (grup 1), 104’ünde ise olağan diş1 epileptik aktivite olmayan (grup 2) toplam 124 hasta çalışmaya dahil edildi. Olağan dışı epileptik aktivitelerden on biri posterior temporal (T5/T6), dördü frontal (F3/F4), dördü frontopolar (Fp1/Fp2), ikisi oksipital

Address for Correspondence/Yazışma Adresi: Ebru Nur Vanlı Yavuz MD, İstanbul University İstanbul Faculty of Medicine, Department of Neurology, Division of Clinical Neurophysiology, İstanbul, Turkey

Phone: +902124142000 E-mail: ebruvanli@hotmail.com

Received/Geliş Tarihi: 23.11.2015 Accepted/Kabul Tarihi: 17.01.2016 


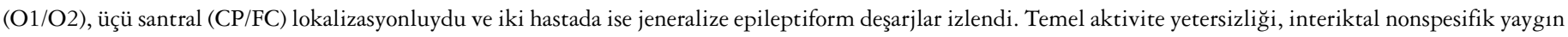

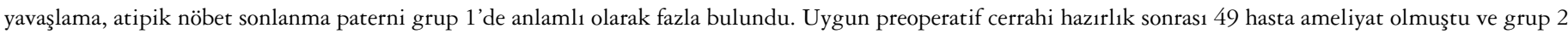
de cerrahi sonrası daha iyi prognoza eğilim olsa da her iki grup arasında ameliyat sonrası prognoz açısından anlamlı farklılık yoktu.

Sonuç: Çalışmamız HS olgularında \%15,9 oranında olağan dışı epileptik odakların görülebildiğine dikkat çekmiştir. Bazı HS olguları bu atipik interiktal EEG bulgularını göstermekle birlikte, uygun şekilde preoperatif incelemeleri yapıldı̆̆ında, iyi post-operatif prognoz gösterebilmektedir.

Anahtar Kelimeler: Mezyal temporal lop epilepsisi, hipokampal skleroz, elektroensefalografi, prognoz

\section{Introduction}

One of the most important causes of drug-resistant focal epilepsies is mesial temporal lobe epilepsy (MTLE). Histopathologically, MTLE is known to be associated with hippocampal sclerosis (HS) $(1,2,3)$. Magnetic resonance imaging (MRI) has been shown to be a highly sensitive diagnostic method in HS diagnosis and with $3 \mathrm{~T}$ MRI, the rate of HS in patients with MTLE reaches nearly $28 \%$ (4). Although there are patients with HS who are responsive to anti-epileptic drugs (AED), most patients in this group are AED resistant. Many previous studies have demonstrated that $40-90 \%$ of patients become epilepsyfree after well-planned surgeries $(5,6)$. Inter-ictal and ictal electroencephalography (EEG) records are very useful in the presurgical evaluation of AED- resistant patients. Patients with HS EEG may be normal or show characteristic findings. Spikes, sharp waves, and sharp and slow wave complexes in anterior temporal electrodes are typical epileptiform findings of inter-ictal EEG. The findings may be unilateral, bilateral, isolated, independent from each other or synchronized. In characteristic EEG, the maximum potential is seen in sphenoidal, T1/2, and/or frontotemporal (F7/8, T3/T4) electrodes (7). In addition, different epileptic activities are sometimes detected in inter-ictal EEGs. In resistant patients whose inter-ictal EEG, clinical, and cranial MRI findings are consistent with HS, the next step is lateralization and localization of the seizure $(8,9)$. Sometimes the result of this diagnostic examination is unsuccessful despite performing all evaluations appropriately, the reasons for this failure are not clearly known. The aim of our study was to compare the clinical, electrophysiologic, and prognostic features of patients with unusual epileptic foci or activities with those with typical epileptic foci or activities.

\section{Materials and Methods}

\section{Patient Selection}

This study included patients temporal lobe epilepsy, who were being treated by the Neurology Department of İstanbul University İstanbul Faculty of Medicine, and came for a follow-up visit between 2013 and 2014 and had at least one EEG evaluation. The study protocol was approved by the ethics committee of İstanbul University Faculty of Medicine and the patients were included after they signed informed consent forms. Available MRI scans were reevaluated. Atrophy of hippocampal structures and increased signal intensity in T2 or FLAIR sequences in scans that were performed under standard epilepsy protocol using a 1.5 tesla (T) MRI device were reviewed $(9,10)$. 3T MRI was performed in patients with indeterminate HS. After MRI evaluations, patients with dual pathologies underwent surgery but patients whose pathology results were not consistent with HS or patients whose
HS diagnosis could not be confirmed with MRI were excluded. 3T MRI was performed in seven patients to obtain a definite diagnosis, three of which were detected to have bilateral HS. Demographic and clinical data such as age, duration of follow-up, age of first seizure, presence of bilateral or a unilateral HS, history of status epilepticus, drug resistance, presence of mental retardation, febrile seizure, febrile status epilepticus, or familial history of epilepsy were recorded on a standard form. Seizure semiology and syndrome classification were performed in accordance with the International League Against Epilepsy (ILAE) criteria (11). The patients' auras were evaluated in accordance with ILAE terminology (12). Patients whose seizures persisted despite mono- or combined treatment with 2 AEDs were defined as 'resistant epilepsy' (13). Postoperative epilepsy status was determined in accordance with the Engel classification (14). Febrile status epilepticus was defined as a seizure in a neurologically-normal child aged 6-50 months of more than 30 minutes duration that did not originate from the central nervous system (15). Diagnosis of mental retardation was made clinically or during a neuropsychometric test. Patients were called by telephone in the event that their data were incomplete.

\section{Electrophysiologic Assessments}

All available electrophysiologic findings (routine EEG, longterm video-EEG monitoring (VEM), and invasive EEG) were independently evaluated by 2 epileptologists at different times. The following were reviewed and recorded using a standard form: basic activity failure in inter-ictal EEG records; temporal intermittent rhythmic delta activity; frontal intermittent rhythmic delta activity (16); inter-ictal nonspecific slowing (generalized or regional slowing) and increase in epileptic activity during hyperventilation; intermittent photic stimulation and sleep; seizure initiation pattern in ictal EEG records (unilateral or bilateral); seizure initiation rhythm (theta or delta); dominant seizure rhythm (theta, delta, alpha or fast rhythm); and seizure ending rhythm (theta, delta, alpha, or fast rhythm). All EEG activities were evaluated, and the patients were then classified as those with or without epileptic foci outside T1/2, F7/8, T3/4 (groups 1 and 2, respectively).

\section{Statistical Analysis}

SPSS 20.0 package program was used for statistical evaluation and $\mathrm{p}<0.05$ was accepted as the limit for significance. Descriptive analyses and Chi-square test or Fisher's exact test for betweengroup analyses were used.

\section{Results}

This study included a total of 124 patients (49 women and 75 men) who met the study criteria including confirmation of HS 
diagnoses. A patient whose MRI findings were consistent with HS during follow-ups but postsurgical pathologic evaluation was not consistent with HS was excluded. Two independent senior electrophysiologists reviewed 389 routine EEG recordings with a total duration of 14394.5 hours, 109 VEM, 12 invasive EEGs, and 416 ictal records. There were 20 patients with unusual interictal epileptic activities (group 1), and 104 patients with typical epileptic activities (group 2). Figure 1, 2 shows examples of the patients' typical and unusual epileptic activities. Unusual foci were detected in 1 area in ten patients, and in at least 2 different areas in 10 patients. Among them, 110 EEG evaluations (85 routines, 23 VEM, 2 invasive) belonged to the unusual epileptic activity group. Among unusual epileptic activities, 11 were at T5/T6, 4 were at $\mathrm{Fp} 1 / \mathrm{Fp} 2,2$ were at $\mathrm{O} 1 / \mathrm{O} 2$, and 3 were at $\mathrm{CP} /$ FC. Generalized epileptic activity was observed in two patients. Among the 20 patients with unusual foci, nine were men and 11
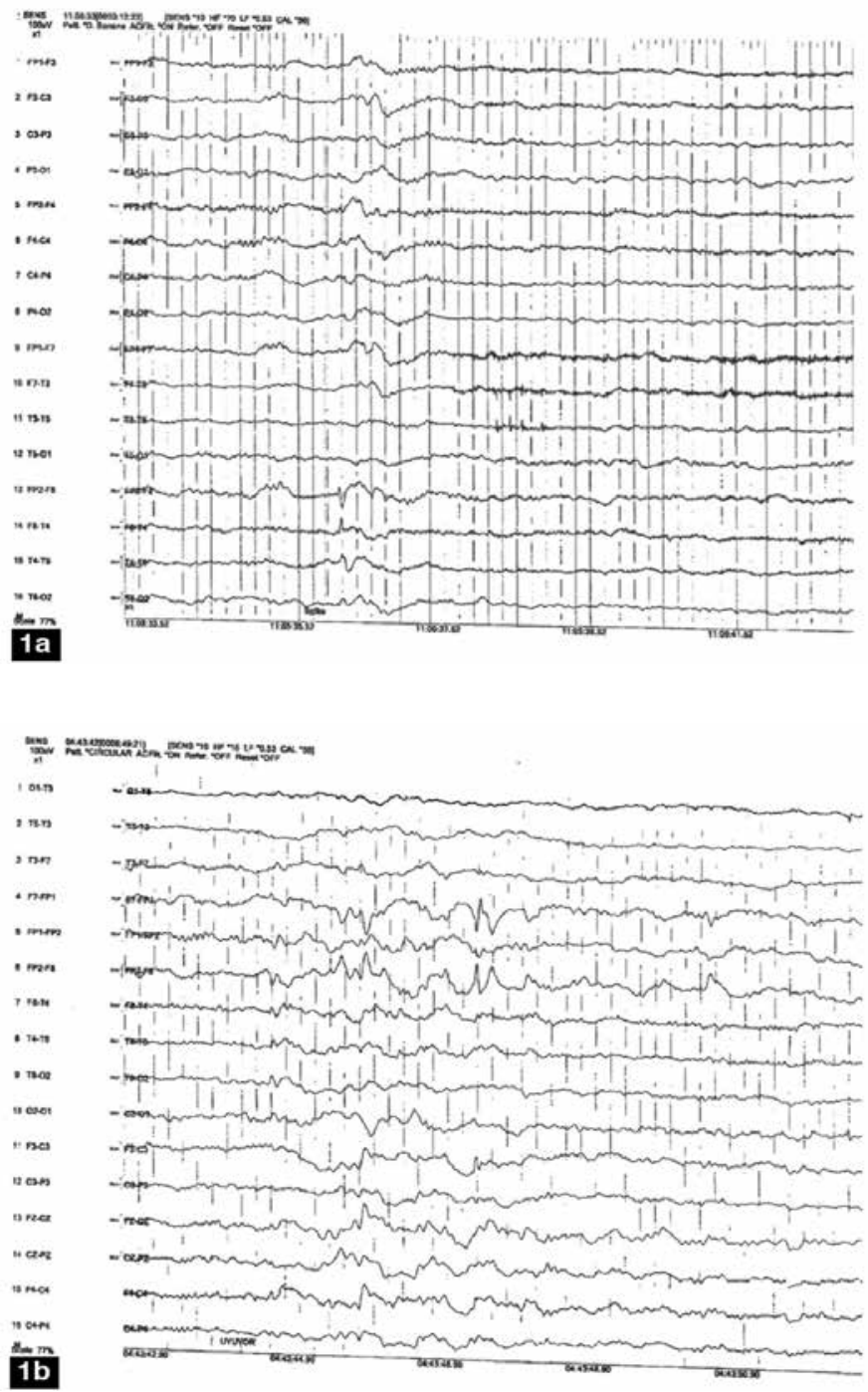

Figure 1a, 1b. Classical and unusual samples of epileptic activity, 1a) F8 focus, 1b) Fp1 focus in the same patient women. Eight (40\%) patients were diagnosed as having bilateral HS. All patients except three $(13 \%)$ were treatment resistant. No statistically significant difference was detected between groups with regards to clinical features and semiologic findings. There was a statistically significant difference between groups according to basic activity failure, inter-ictal nonspecific slowing, and seizure ending pattern $(\mathrm{p}=0.003, \mathrm{p}=0.024$, and $\mathrm{p}=0.048$, respectively). Forty-nine of the patients had undergone previous surgeries: 17 for right HS, 23 for left HS, and 9 for bilateral HS. It was striking that there was no difference between the groups according to duration of epilepsy-free periods after surgery. Table 1 demonstrates the detailed clinical, electrophysiologic, and postoperative results of groups 1 and 2 .

\section{Discussion}

In our study, unusual epileptic activity in addition to foci that are expected in patients with MTLE-HS were detected in $16.1 \%$ of all patients with HS. Similar to our study, the rate of lateral temporal and extra-temporal foci was found as $17.7 \%$ in patients with amygdala lesions and $20 \%$ in individuals with MTLE-HS who were included as a control group (17). Unusual foci are located at different places and the features of the patients do not indicate a specific sub-type. A comparison of an AED-resistant MTLE group with a non-resistant group showed that inter-ictal epileptic or nonspecific anomalies have an effect on prognosis $(18,19)$. However, in our study it was interesting that there was no difference between groups according to prognosis or drug resistance despite a difference in basic activity failure, nonspecific anomaly or seizure type. When inter-ictal foci are multifocal or bilateral they may negatively affect seizure control in the postoperative period. On the other hand, no difference was found according to seizure control.

In summary, the effects of inter-ictal findings in prognosis are still controversial $(20,21)$. In accordance with the findings of our study, inter-ictal spikes originate from neocortical structures instead of mesial temporal structures and noninvasive EEG does

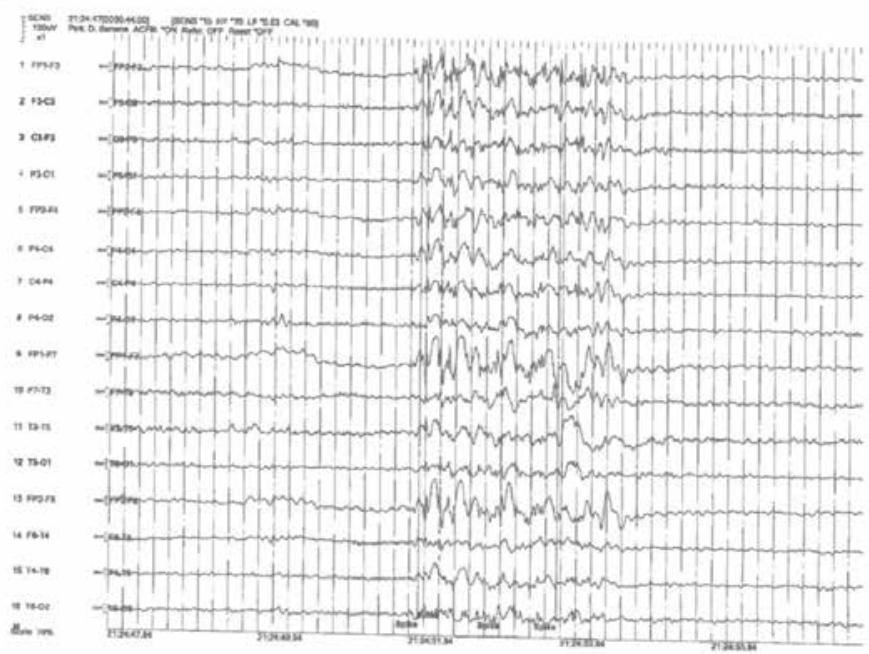

Figure 2. Generalized epileptic activity during intermittent photic stimulation 
Table 1. The clinical, electrophysiological and postoperative comparisons of groups 1 and 2

\begin{tabular}{|c|c|c|c|}
\hline & $\begin{array}{l}\text { Grup } 1 \\
(n=20)\end{array}$ & $\begin{array}{l}\text { Grup } 2 \\
(n=104)\end{array}$ & $\begin{array}{l}\text { Statistical } \\
\text { significance }\end{array}$ \\
\hline Current age, years, mean (SD) & $34.45(6.48)$ & $39.06(11.10)$ & Not significant \\
\hline Follow-up duration, months, mean (SD) & $97.00(61.33)$ & $94.63(87.42)$ & Not significant \\
\hline Male/female, $\mathrm{n}$ & $9 / 11$ & $40 / 64$ & Not significant \\
\hline Age at seizure onset, years, mean (SD) & $13.90(9.90)$ & $13.25(11.39)$ & Not significant \\
\hline Bilateral HS, n (\%) & $8(40.0)$ & $23(22.1)$ & Not significant \\
\hline Status epilepticus, n (\%) & $5(25.0)$ & $14(13.5)$ & Not significant \\
\hline Drug resistance, $\mathrm{n}(\%)$ & $17(85.0)$ & $85(81.7)$ & Not significant \\
\hline Mental retardation, $\mathrm{n}(\%)$ & $4(20.0)$ & $17(16.3)$ & Not significant \\
\hline History of febrile seizure & $15(75.0)$ & $65(62.5)$ & Not significant \\
\hline History of febrile status epilepticus, n (\%) & $5(25.0)$ & $14(14.1)$ & Not significant \\
\hline Family history of epilepsy, n (\%) & $6(30.0)$ & $29(27.9)$ & Not significant \\
\hline \multicolumn{3}{|l|}{ EEG } & $<0.003^{*}$ \\
\hline TIRDA, n (\%) & $3(15.0)$ & $32(30.8)$ & Not significant \\
\hline FIRDA, n (\%) & $13(65.0)$ & $44(73.3)$ & Not significant \\
\hline $\begin{array}{l}\text { Interictal nonspecific slowing, } \mathrm{n}(\%)^{*} \\
\text { Diffuse } \\
\text { Regional } \\
\text { Absent }\end{array}$ & $\begin{array}{l}9(45.0) \\
9(45.0) \\
2(10.0)\end{array}$ & $\begin{array}{l}18(17.3) \\
59(56.7) \\
27(26.0)\end{array}$ & $0.024^{* *}$ \\
\hline Activation of foci during HV, n (\%) & $3(15.0)$ & $20(19.2)$ & Not significant \\
\hline Activation of foci during IPS, n (\%) & $1(5.0)$ & $1(1.0)$ & Not significant \\
\hline Activation of foci during sleep, n (\%) & $2(10.0)$ & $22(21.2)$ & Not significant \\
\hline $\begin{array}{l}\text { Ictal EEG: } 109 \text { VEM in } 79 \text { patients**** } \\
\text { Unilateral seizure onset, } \mathrm{n}(\%) \\
\text { Bilateral seizure onset, } \mathrm{n}(\%) \\
\text { Undetermined seizure onset, } \mathrm{n}(\%)\end{array}$ & $\begin{array}{l}9(64.3) \\
1(7.1) \\
4(28.6)\end{array}$ & $\begin{array}{l}38(66.7) \\
4(7.0) \\
15(26.3)\end{array}$ & Not significant \\
\hline $\begin{array}{l}\text { Seizure onset pattern, } \mathrm{n}(\%) \\
\text { Rhythmic theta, } \mathrm{n}(\%) \\
\text { Rhythmic delta, n (\%) } \\
\text { Other (undetermined or suppression), n (\%) }\end{array}$ & $\begin{array}{l}5(35.7) \\
1(7.1) \\
8(57.1)\end{array}$ & $\begin{array}{l}32(56.1) \\
3(5.3) \\
22(38.6)\end{array}$ & Not significant \\
\hline $\begin{array}{l}\text { Dominant seizure rhythm, n (\%) } \\
\text { Rhythmic theta, } \mathrm{n}(\%) \\
\text { Rhythmic delta, n (\%) } \\
\text { Other (alpha/fast activity, n (\%) }\end{array}$ & $\begin{array}{l}12(85.7) \\
1(7.1) \\
1(7.1)\end{array}$ & $\begin{array}{l}47(82.5) \\
3(5.3) \\
7(12.3)\end{array}$ & Not significant \\
\hline $\begin{array}{l}\text { Seizure offset pattern, n (\%) } \\
\text { Rhythmic theta, n (\%) } \\
\text { Rhythmic delta, n (\%) } \\
\text { Other (alpha/fast activity), n (\%) }\end{array}$ & $\begin{array}{l}1(7.1) \\
7(50.0) \\
6(42.9)\end{array}$ & $\begin{array}{l}8(14.0) \\
42(73.7) \\
7(12.3)\end{array}$ & $0.048^{* *}$ \\
\hline Total operated patients, n (\%) & $9(45.0)$ & $40(42.5)$ & Not significant \\
\hline $\begin{array}{l}\text { Postoperative follow up duration, years, } \\
\text { mean (SD) }\end{array}$ & $3.00(3.36)$ & $3.92(3.05)$ & Not significant \\
\hline Engel I/II-IV classification, $\mathrm{n}$ & $6 / 3$ & $36 / 4$ & Not significant \\
\hline $\begin{array}{l}\text { EEG: Electroencephalography, SD: Standard deviation, } \mathrm{H} \\
\text { rhythmic delta activity, FIRDA: Frontal intermittent rhyt } \\
\text { stimulation, VEM: Video-electroencephalography monito } \\
\text { unavailable, three patient did not have seizure during vi }\end{array}$ & "Chi-square test & $\begin{array}{l}\text { n: Number, TIRDA: } \\
\text { Hyperventilation, II } \\
\text { sher's exact test, }{ }^{* * *} \\
\text { hy }\end{array}$ & $\begin{array}{l}\text { Temporal intermittent } \\
\text { : Intermittent photic } \\
\text { ive patients data was }\end{array}$ \\
\hline
\end{tabular}


not have a good localizing effect (22). A study by Pittau et al in a group of AED resistant and non-resistant patients showed that different inter-ictal EEG findings have adverse effects on prognosis (18). We mostly chose our patients from the AEDresistant group because our center is a tertiary level epilepsy center. If we had studied a group with less resistant patients, our findings about inter-ictal unusual epileptic activities might have changed and its effects on prognosis might have been different. Although the underlying mechanism of atypical inter-ictal foci is not known, it can be speculated that dysplasia at the microscopic level that cannot be detected in MRI may be causative. The greater impairment of basic activity in this group and relatively more frequent presence of inter-ictal nonspecific slow waves suggest an initial precipitating event (birth trauma, head trauma or silent limbic encephalitis), which causes more global impairment.

There are studies that claimed absence of a negative impact of dual pathology in patients with anterior temporal lobectomy and selective amygdalohippocampectomy $(23,24,25)$. Another study found that bilateral amygdalohippocampal atrophy was common in temporal lobe developmental anomalies and negatively affected prognosis (26). Although we excluded dual pathology in our study with MRI, we selected patients who met $1.5 \mathrm{~T}$ MRI criteria. However, if we could have investigated with different and more sensitive diagnostic methods we would have seen comorbid dual or other pathologies. A higher frequency of patients with HS among our group with usual foci was noticeable; however, it did not reach statistical significance. In two patients with generalized type and photosensitive epileptiform anomalies, it was controversial as to whether this clinical picture was a comorbid genetic syndrome or a fast secondary bilateral hypersynchronization. We do not have information such as invasive EEG, history of epilepsy in the family, and detection of mutations to definitely diagnose these patients.

\section{Conclusion}

In conclusion, atypical inter-ictal epileptiform anomalies have been detected in some patients. Although this was a heterogeneous group, the rate of epilepsy-free patients was not different from those with typical inter-ictal EEG findings with good pre-surgical planning.

\section{Ethics}

Etbics Committee Approval: The study were approved by the Istanbul University Istanbul Faculty of Medicine of Local Ethics Committee. Informed Consent: Consent form was filled out by all participants. Peer-review: Externally peer-reviewed.

\section{Authorship Contributions}

Surgical and Medical Practices: Nerses Bebek, Candan Gürses, Aysen Gökyiğit, Betül Baykan, Concept: Ebru Nur Vanlı Yavuz, Design: Ebru Nur Vanlı Yavuz, Betül Baykan, Data Collection or Processing: Ebru Nur Vanlı Yavuz, Hakan Yener, Zeynep Aydin Özemir, Analysis or Interpretation: Ebru Nur Vanlı Yavuz, Betül Baykan, Literature Search: Ebru Nur Vanlı Yavuz, Writing: Ebru Nur Vanlı Yavuz, Zeynep Aydin Özemir, Betül Baykan.

Conflict of Interest: No conflict of interest was declared by the authors.
Financial Disclosure: The authors declared that this study has received no financial support.

\section{References}

1. Blümcke I, Thom M, Aronica E, Armstrong DD, Bartolomei F, Bernasconi A, Bernasconi N, Bien CG, Cendes F, Coras R, Cross JH, Jacques TS, Kahane P, Mathern GW, Miyata H, Moshé SL, Oz B, Özkara Ç, Perucca E, Sisodiya S, Wiebe S, Spreafico R. International consensus classification of hippocampal sclerosis in temporal lobe epilepsy: a Task Force Report from the ILAE Commission on Diagnostic Methods. Epilepsia 2013;54:1315-1329.

2. Cendes F, Sakamoto AC, Spreafico R, Bingaman W, Becker AJ. Epilepsies associated with hippocampal sclerosis. Acta Neuropathol 2014;128:21-37.

3. Du X, Usui N, Terada K, Baba K, Matsuda K, Tottori T, Inoue Y. Semiological and electroencephalographic features of epilepsy with amygdalar lesion. Epilepsy Res 2015;111:45-53.

4. Coan AC, Kubota B, Bergo FP, Campos BM, Cendes F. 3T MRI quantification of hippocampal volume and signal in mesial temporal lobe epilepsy improves detection of hippocampal sclerosis. AJNR Am J Neuroradiol 2014;35:77-83.

5. Yasuda CL, Tedeschi H, Oliveira EL, Ribas GC, Costa AL, Cardoso TA, Montenegro MA, Guerreiro CA, Guerreiro MM, Li LM, Cendes F. Comparison of short-term outcome between surgical and clinical treatment in temporal lobe epilepsy: a prospective study. Seizure 2006;15:35-40.

6. Wiebe S, Blume WT, Girvin JP, Eliasziw M; A randomized, controlled trial of surgery for temporal-lobe epilepsy. Effectiveness and Efficiency of Surgery for Temporal Lobe Epilepsy Study Group. N Engl J Med 2001;345:311-318.

7. Blume WT. The necessity for sphenoidal electrodes in the presurgical evaluation of temporal lobe epilepsy: con position. J Clin Neurophysiol 2003;20:305-310.

8. Rosenow F, Lüders H. Presurgical evaluation of epilepsy. Brain 2001;124:1683-700.

9. Sirin NG, Gurses C, Bebek N, Dirican A, Baykan B, Gokyigit A. A quadruple examination of ictal EEG patterns in mesial temporal lobe epilepsy with hippocampal sclerosis: onset, propagation, later significant pattern, and termination. J Clin Neurophysiol 2013;30:329-338.

10. Cendes F, Andermann F, Gloor P, Evans A, Jones-Gotman M, Watson C, Melanson D, Olivier A, Peters T, Lopes-Cendes I. MRI volumetric measurement of amygdala and hippocampus in temporal lobe epilepsy. Neurology 1993;43:719-725.

11. Berg AT, Berkovic SF, Brodie MJ, Buchhalter J, Cross JH, van Emde Boas W, Engel J, French J, Glauser TA, Mathern GW, Moshé SL, Nordli D, Plouin P, Scheffer IE. Revised terminology and concepts for organization of seizures and epilepsies: report of the ILAE Commission on Classification and Terminology, 2005-2009. Epilepsia 2010;51:676-685.

12. Blume WT, Lüders HO, Mizrahi E, Tassinari C, van Emde Boas W, Engel J Jr. Glossary of descriptive terminology for ictal semiology: report of the ILAE task force on classification and terminology. Epilepsia 2001;42:12121218.

13. Kwan P, Arzimanoglou A, Berg AT, Brodie MJ, Allen Hauser W, Mathern G, Moshé SL, Perucca E, Wiebe S, French J. Definition of drug resistant epilepsy: consensus proposal by the ad hoc Task Force of the ILAE Commission on Therapeutic Strategies. Epilepsia 2010;51:1069-1077.

14. Wieser HG, Blume WT, Fish D, Goldensohn E, Hufnagel A, King D, Sperling MR, Lüders H, Pedley TA. ILAE Commission Report. Proposal for a new classification of outcome with respect to epileptic seizures following epilepsy surgery. Epilepsia 2001;42:282-286.

15. Scott RC, King MD, Gadian DG, Neville BG, Connelly A. Hippocampal abnormalities after prolonged febrile convulsion: a longitudinal MRI study. Brain 2003;126:2551-2557.

16. Brigo F. Intermittent rhythmic delta activity patterns. Epilepsy Behav 2011;20:254-256.

17. Du X, Usui N, Terada K, Baba K, Matsuda K, Tottori T, Inoue Y. Semiological and electroencephalographic features of epilepsy with amygdalar lesion. Epilepsy Res 2015;111:45-53.

18. Pittau F, Bisulli F, Mai R, Fares JE, Vignatelli L, Labate A, Naldi I, Avoni P, Parmeggiani A, Santucci M, Capannelli D, Di Vito L, Gambardella A, Baruzzi A, Tinuper P. Prognostic factors in patients with mesial temporal lobe epilepsy. Epilepsia 2009;50:41-44. 
19. Sànchez J, Centanaro M, Solís J, Delgado F, Yepez L. Factors predicting the outcome following medical treatment of mesial temporal epilepsy with hippocampal sclerosis. Seizure 2014;23:448-453.

20. Schulz R, Lüders HO, Hoppe M, Tuxhorn I, May T, Ebner A. Interictal EEG and ictal scalp EEG propagation are highly predictive of surgical outcome in mesial temporal lobe epilepsy. Epilepsia 2000;41:564-570.

21. Malter MP, Bahrenberg C, Niehusmann P, Elger CE, Surges R. Features of scalp EEG in unilateral mesial temporal lobe epilepsy due to hippocampal sclerosis: Determining factors and predictive value for epilepsy surgery. Clin Neurophysiol 2015;127:1081-1087.

22. Wennberg R, Valiante T, Cheyne D. EEG and MEG in mesial temporal lobe epilepsy: where do the spikes really come from? Clin Neurophysiol 2011;122:1295-1313.
23. Prayson BE, Prayson RA, Kubu CS, Bingaman W, Najm IM, Busch RM Effects of dual pathology on cognitive outcome following left anterior temporal lobectomy for treatment of epilepsy. Epilepsy Behav 2013;28:426-431.

24. Savitr Sastri BV, Arivazhagan A, Sinha S, Mahadevan A, Bharath RD, Saini J, Jamuna R, Kumar JK, Rao SL, Chandramouli BA, Shankar SK, Satishchandra P. Clinico-pathological factors influencing surgical outcome in drug resistant epilepsy secondary to mesial temporal sclerosis. J Neurol Sci 2014;340:183190.

25. Varoglu AO, Saygi S, Acemoglu H, Ciger A. Prognosis of patients with mesial temporal lobe epilepsy due to hippocampal sclerosis. Epilepsy Res 2009;85:206-211.

26. Kuzniecky R, Ho SS, Martin R, Faught E, Morawetz R, Palmer C, Gilliam F. Temporal lobe developmental malformations and hippocampal sclerosis: epilepsy surgical outcome. Neurology 1999;52:479-484. 